\title{
PEMANFATAAN LIMBAH INDUSTRI MINYAK KELAPA (BUNGKIL KOPRA) DALAM PAKAN PEMBESARAN IKAN BARONANG (Siganus guttatus) DI KERAMBAJARING APUNG
}

\author{
Kamaruddin \\ Balai Penelitian dan Pengembangan Budidaya Air Payau \\ Jl. Makmur Dg. Sitakka No. 129, Maros 90512, Sulawesi Selatan \\ E-mail: dgbilla@yahoo.com
}

\begin{abstract}
ABSTRAK
Usaha budidaya ikan secara intensif menuntut tersedianya pakan dalam jumlah yang cukup, berkualitas, tepat waktu, dan berkesinambung. Pemanfaatan bahan baku lokal yang berasal dari limbah industri seperti bungkil kopra dapat digunakan sebagai salah satu bahan penyusun pakan ikan baronang dengan pertimbangan murah, mudah diperoleh, tersedia setiap saat, dan mempunyai kandungan gizi baik. Tujuan kegiatan ini adalah untuk mengetahui apakah dengan penambahan bungkil kopra dalam pakan bisa memberikan respons pertumbuhan pada ikan baronang. Kegiatan ini dilakukan di keramba jaring apung (KJA) menggunakan waring hitam ukuran $1 \mathrm{~m}$ x $1 \mathrm{~m}$ x 2 m, dengan kepadatan 37 ekor. Benih yang digunakan berasal dari alam dengan bobot rata-rata $84,10 \mathrm{~g} /$ ekor. Penambahan bungkil kopra ke dalam pakan pembesaran ikan baronang sebanyak $43 \%$, dapat memberikan laju pertambahan bobot 76,4 $\mathrm{g}$ dan sintasan $75,7 \%$ selama 90 hari pemeliharaan.
\end{abstract}

KATA KUNCI: bungkil kopra, usaha budidaya

\section{PENDAHULUAN}

Ikan baronang (Siganus guttatus Bloch) termasuk ikan laut yang mempuyai nilai ekonomi tinggi, karena selain dikonsumsi dalam negeri juga merupakan komoditi ekspor. Sampai saat ini, produksi ikan baronang masih mengandalkan hasil tangkapan dari alam, sementara permintaan terus meningkat. Sejalan dengan permintaan yang terus meningkat diikuti pula oleh harga ikan baronang yang membaik sehingga perburuan terhadap ikan ini tidak dapat dihindari, sehingga dapat mengancam populasinya.
Kegiatan penangkapan secara intensif tidak dapat dilakukan terus-menerus jika tidak diimbangi dengan kegiatan perbenihan, restocking, dan budidaya. Upaya perbenihan serta budidaya merupakan keharusan untuk memenuhi permintaan yang terus meningkat dan mencegah penurunan populasi, serta kepunahan spesies tertentu seperti baronang. Usaha budidaya ikan secara intensif menuntut tersedianya pakan dalam jumlah yang cukup, berkualitas, tepat waktu, dan berkesinambungan (Alamsyah, 2005).

Pemanfaatan bahan baku lokal diharapkan dapat digunakan dalam pembuatan pakan dengan pertimbangan murah, mudah diperoleh, tersedia setiap saat, serta mempunyai kandungan gizi baik untuk menekan biaya pakan. Hasil survai mengenai ketersediaan bahan baku lokal pada tahun 1998/1999 di 23 Kabupaten di Sulawesi Selatan, sebagai salah satu upaya untuk mendapatkan beberapa bahan yang potensial untuk mensubstitusi bahan impor dalam pembuatan pakan ikan.

Jenis bahan baku lokal tersebut adalah ikan rucah, rebon, kepala udang sebagai limbah cold storage, limbah dari tempat pemotogan hewan, limbah pabrik tapioka, limbah kelapa sawit, dan dedak halus, serta hasil analisis komposisi nutrisi menunjukkan bahwa ikan rucah, rebon, kepala udang, darah, dapat mensubstitusi tepung ikan, dan bungkil kedelai merupakan jenis bahan potensial yang selama ini diimpor (Palinggi et al., 2002).

Ampas kopra merupakan hasil ikutan yang diperoleh dari ekstraksi daging buah kelapa kering (Woodrof, 1979). Bungkil kopra masih mengandung protein, karbohidrat, mineral, dan sisa-sisa minyak yang masih tertinggal (Child, 
1964). Karena kandungan protein yang cukup tinggi (16\%18\%), dengan demikian pemanfaatan bungkil kopra dalam pakan pembesaran ikan khususnya jenis ikan herbivora seperti ikan baronang perlu dilakukan.
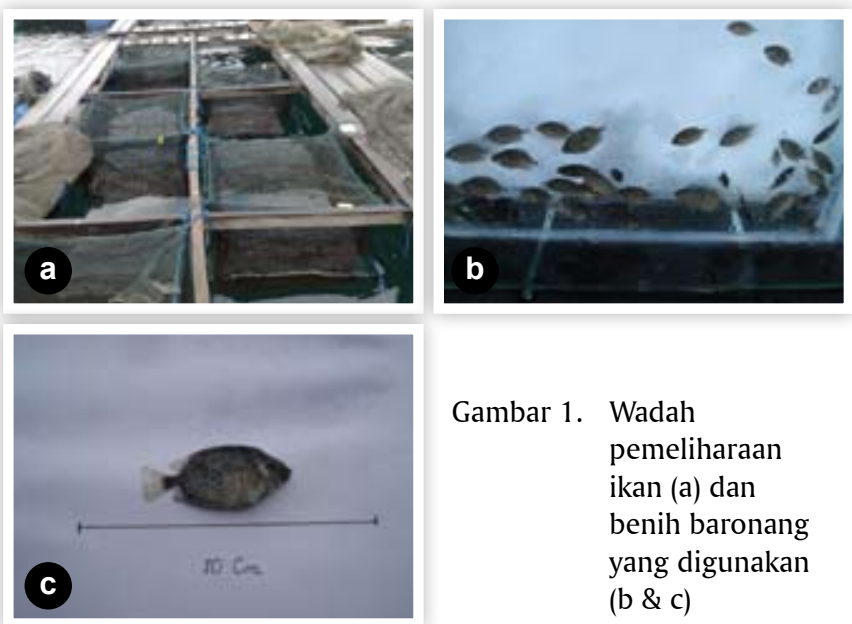

Gambar 1. Wadah pemeliharaan ikan (a) dan benih baronang yang digunakan (b \& c)

\section{Pelaksanaan Kegiatan}

Kegiatan ini dilakukan di keramba jaring apung menggunakan waring hitam ukuran $1 \mathrm{~m} \times 1 \mathrm{~m} \times 2 \mathrm{~m}$ (Gambar 1A) dengan kepadatan 37 ekor, serta bobot ratarata 84,10 g/ekor (Gambar 1B dan 1C). Penambahan bungkil kopra dalam pakan sebanyak 43\%. Peubah yang diamati adalah pertumbuhan ikan meliputi pertambahan bobot dan sintasan. Sampling dilakukan setiap empat minggu, dengan mengukur bobot baronang. Untuk menghindari ikan memberontak pada saat penimbangan, maka dilakukan pembiusan menggunakan minyak cengkeh dengan dosis 10 $\mathrm{mg} / \mathrm{L}$. Kegiatan ini berlangsung selama 3 bulan. Perlakuan yang dicobakan adalah pakan yang terdiri atas campuran beberapa bahan baku lokal yang didominasi oleh bungkil kopra 43\% (Tabel 2) dengan 3 kali ulangan. Pemberian pakan dilakukan sebanyak 3 kali sehari yaitu pagi hari (pukul 08.00), siang hari (pukul 12.00), dan sore hari (pukul 16.00) dengan dosis 3\% dari biomassa ikan.

\section{Formulasi Pakan yang Digunakan}

Sesuai dengan prosedur dalam penyusunan formulasi pakan ikan, semua bahan baku yang digunakan dalam penyusunan formulasi pakan, terlebih dahulu dilakukan uji proksimat untuk mengetahui komposisi nutrizi dari masing-masing bahan baku (Tabel 1). Selanjutnya dibuat formulasi pakan yang disesuaikan dengan kebutuhan
Tabel 1. Komposisi nutrisi pada masing-masing bahan yang digunakan dalam formulasi pakan

\begin{tabular}{cccccc}
\hline & \multicolumn{5}{c}{ Parameter (\% kering) } \\
\cline { 2 - 6 } Bahan & Protein & Lemak & $\begin{array}{c}\text { Serat } \\
\text { kasar }\end{array}$ & $\begin{array}{c}\text { Kadar } \\
\text { abu }\end{array}$ & BETN \\
\hline $\begin{array}{c}\text { Tepung } \\
\text { ikan }\end{array}$ & 65,6 & 4,8 & 2,8 & 12,6 & 14,2 \\
$\begin{array}{c}\text { Tepung } \\
\text { kepala } \\
\text { udang }\end{array}$ & 49,8 & 2 & 3 & 25,1 & 20,1 \\
$\begin{array}{c}\text { Sagu } \\
\text { Bungkil } \\
\text { kopra }\end{array}$ & 8,51 & 0 & 3,2 & 1,96 & 86,33 \\
\hline
\end{tabular}

Sumber: Palinggi et al. (2002)

Tabel 2. Formulasi pakan dengan pemanfaatan bungkil kopra dalam pembesaran ikan baronang

\begin{tabular}{lc}
\hline \multicolumn{1}{c}{ Bahan } & Pakan uji (\%) \\
\hline Tepung ikan & 14 \\
Tepung kepala udang & 10 \\
Sagu & 28 \\
Bungkil kopra & 43 \\
Minyak ikan & 3 \\
Vitamin + mineral & 2 \\
\hline Hasil proksimat: & \\
Protein & 34,92 \\
Lemak & 4,76 \\
BETN & 41,88 \\
\hline
\end{tabular}

nutrisi ikan yang akan dipelihara, agar pakan yang dibuat dapat dimanfaatkan secara optimal sehingga memberikan pertumbuhan yang maksimal (Tabel 2).

Bungkil kopra yang diperoleh dari pabrik minyak kelapa teksturnya masih kasar atau berbentuk gumpalangumpalan, sehingga perlu pengolahan terlebih dahulu, seperti penepungan dengan menggunakan saringan kasar $\varnothing$ $2 \mathrm{~mm}$. Selanjutnya ditepungkan lagi dengan menggunakan saringan yang halus $\emptyset 0,5 \mathrm{~mm}$; tepung bungkil kopra siap dicampurkan dengan bahan lain sesuai persentase dalam formulasi pakan (Tabel 2).

Dari Tabel 1 terlihat bahwa komposisi nutrisi bungkil kopra sebagai sumber protein nabati cukup tinggi bila dibandingkan dengan bahan limbah lainnya seperti bungkil kelapa sawit $(10,6 \%)$ dan dedak halus $(13,8 \%)$; selain itu, juga 
kandungan serat kasarnya lebih rendah bila dibandingkan dengan bungkil kelapa sawit $(31,8 \%)$ dan dedak $(14,3 \%)$. Sehingga lebih mudah dimanfaatkan oleh ikan baronang, sebab tingkat pemanfaatan bahan baku dipengaruhi antara lain oleh serat kasar. Menurut Nyina-Wamwiza et al. (2010), kandungan serat kasar bahan yang tinggi dalam pakan dapat menyebabkan kecernaan bahan kering dan energi pakan menjadi rendah.

\section{Peranan Bungkil Kopra dalam Pakan untuk Menunjang Pertumbuhan Ikan Baronang}

Selama pemeliharaan 90 hari dalam keramba jaring apung, diperoleh bahwa ikan baronang memberikan respons biologi terhadap pertambahan bobot, laju pertumbuhan harian, dan sintasan dapat dilihat pada Tabel 3.

Tabel 3. Respons biologi ikan baronang terhadap pemanfaatan bungkil kopra dalam pakan pembesaran ikan baronang selama 90 hari di keramba jaring apung

\begin{tabular}{lc}
\hline \multicolumn{1}{c}{ Parameter } & Pakan uji \\
\hline Rataan bobot awal $(\mathrm{g})$ & $84,1 \pm 4,69$ \\
Rataan bobot akhir $(\mathrm{g})$ & $160,5 \pm 5,63$ \\
Pertambahan bobot $(\mathrm{g})$ & 76,4 \\
Laju pertumbuhan harian (\%) & 0,15 \\
Sintasan (\%) & 75,7 \\
\hline
\end{tabular}

Dari Tabel 3 menunjukkan bahwa penggunaan tepung bungkil kopra dalam pakan pembesaran ikan baronang sebanyak $43 \%$, diperoleh pertambahan bobot rata-rata sebesar 76,4 g dengan laju pertumbuhan harian sebesar 0,15\%; sedangkan sintasan diperoleh $75,7 \%$. Seperti yang dilaporkan Palinggi \& Lante (2010) mensubstitusi tepung bungkil kedelai dengan tepung bungkil kopra sebanyak $27 \%$ dalam pakan pembesaran ikan baronang memberikan respons pertumbuhan sama dengan kontrol (tanpa bungkil kopra). Hal ini menunjukkan bahwa ikan baronang bisa memanfaatkan bungkil kopra. Dengan demikian penggunaan tepung bungkil kopra dalam pakan ikan baronang lebih baik daripada tepung bungkil kedelai. Sehingga bungkil kopra dapat mengatasi kesulitan pengadaan tepung bungkil kedelai, karena sampai saat ini sebagian besar kebutuhan kedelai masih diimpor. Usman et al. (2011) melaporkan bahwa ikan bandeng yang dipelihara di tambak dapat memanfaatkan bungkil kopra sebanyak 55\%-65\%, dalam pakan dengan memberikan hasil yang hampir sama dengan perlakuan kontrol (pakan komersil). Hal ini diduga karena komposisi nutrisi bungkil kopra lebih bagus daripada dedak halus yang merupakan bahan utama pakan bandeng komersil. Yamaguchi (1991) menyarankan pakan buatan untuk ikan baronang berkadar protein rendah, dengan memperhatikan kandungan gizi yang sesuai kebutuhannya di alam. Dari hasil penelitian ini diperoleh bahwa ikan baronang dapat memanfaatkan bungkil kopra dalam pakannya. Lante \& Usman (2010) melaporkan bahwa penggunaan lemak sebanyak 5\% dalam pakan cukup untuk mendukung pertumbuhan dan sintasan ikan baronang. Bungkil kopra (Gambar 2) sebagai limbah industri minyak kelapa, masih mengandung lemak yang cukup tinggi dibandingkan dengan limbah industri lainnya, sehingga dapat dijadikan salah satu sumber utama dalam pakan pembesaran ikan baronang.

Seperti yang dilaporkan Pongsapan et al. (1990) ikan baronang dapat diberikan pelet tenggelam dengan kandungan protein $30,4 \%$ sebanyak $6 \%$ dari bobot badan/hari. Meskipun ikan ini sangat respons terhadap pakan buatan (pelet), tetapi perkembangannya belum begitu maju karena harga pakan mahal dan kurang layak bila dibandingkan harga jual ikan baronang. Oleh sebab itu, sangat tepat bila pemanfaatan bahan baku lokal ataupun jenis-jenis limbah industri dioptimalkan dalam usaha budidaya perikanan, sehingga dapat menekan biaya pakan menjadi lebih murah dan akhirnya memberikan keuntungan bagi pembudidaya. Seperti yang dilaporkan oleh Usman et al. (2011) bahwa pakan yang berbahan dasar bungkil kopra (65\%) untuk ikan bandeng harganya Rp 3.500,- - Rp 4.000,-/kg; sedangkan harga pakan komersil yaitu Rp 6.100,-.

Kebiasaan baronang di alam memakan berbagai bahan tumbuhan menggambarkan bahwa baronang mampu memanfaatkan karbohidrat untuk memenuhi kebutuhan energinya, hal ini disebabkan karena ikan baronang tergolong jenis ikan herbivora, sehingga mampu memanfaatkan dan mencerna serat kasar (Burhanuddin, 1987). 


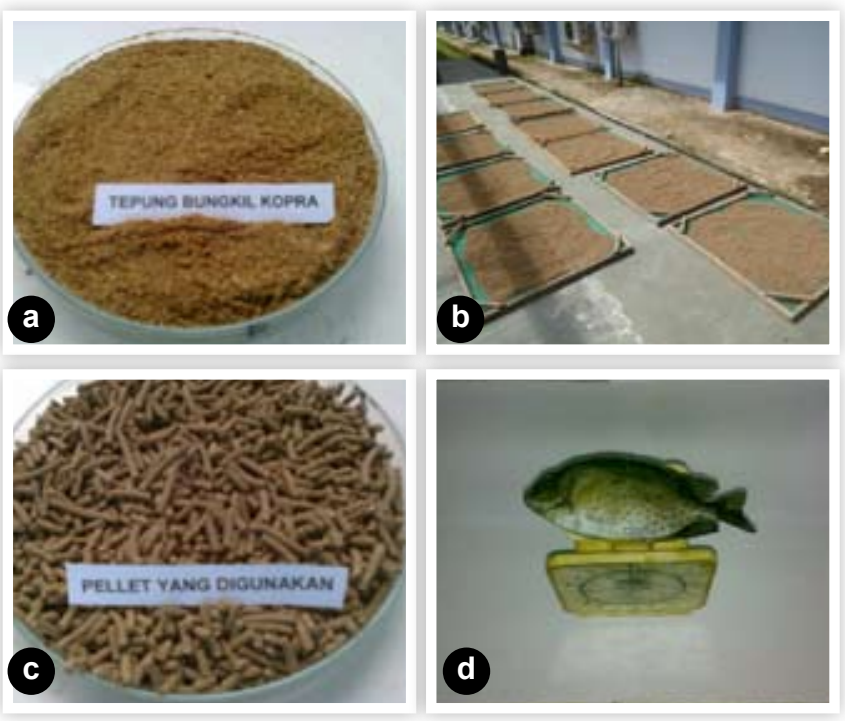

Gambar 2. Tepung bungkil kopra (a); pelet yang sedang dijemur (b); pelet yang siap diberikan pada ikan (c); dan ikan pada akhir pemeliharaan $(\mathrm{d})$

Dari Gambar 2 terlihat warna pelet didominasi warna bungkil, hal ini disebabkan karena bahan baku yang mendominasi pelet tersebut adalah bungkil kopra sebagai bahan dasar pakan tersebut.

\section{KESIMPULAN}

Meskipun bungkil kopra mempunyai serat kasar yang cukup tinggi, tetapi pemanfaatan masih bisa mencapai 43\% dalam pakan pembesaran ikan baronang dan memberikan pertumbuhan yang cukup bagus.

\section{DAFTAR ACUAN}

Alamsyah, R. 2005. Pemanfaatan teknologi komputer untuk menghasilkan pakan berkualitas. Pengolahan pakan ayam dan ikan secara modern. Seri Industri kecil. Penebar Swadaya. Jakarta, 139 hlm.
Burhanuddin. 1987. Pengaruh kadar garam air terhadap pertumbuhan dan angka kematian ikan baronang (Siganus guttatus). J. Pen. Budidaya Pantai, 3(2): 37-48.

Child, R. 1964. Coconut. Longman. London, 76 pp.

Palinggi, N.N., Rachmansyah, \& Asda, L. 2002. Potensi bahan baku pakan lokal di Sulawesi Selatan. Australia-Indonesia Fisheries Showcase. 20 Years of Collaborative Research. Jakarta, 31 Juli 2002.

Lante, S. \& Usman. 2010. Pengaruh pemberian pakan buatan dangan kadar lemak berbeda terhadap pertumbuhan dan sintasan ikan baronang, Siganus guttatus. Prosiding Forum Inovasi Teknologi Akuakultur, $6 \mathrm{hlm}$.

Nyina-Wamwiza, L., Wathele, B., Richir, J., Rollin, X., \& Kestemont, P. 2010. Partial or total replacement of fish meal by local aqricultural by-products in diets of juvenile African catfish (Clarias gariepinus): growth performance, feed efficiency and digestibility. Aquaculture Nutrition, 16: 237-247.

Palinggi, N.N. \& Samuel, L. 2010. Substitusi tepung bungkil kedelai dengan tepung bungkil kopra dalam pakan ikan baronang, Siganus guttatus. Prosiding Forum Inovasi Teknologi Akuakultur, $5 \mathrm{hlm}$.

Sundu, B., Kumar, A., \& Dingle, J. 2009. Feeding value fo copra meal for broiler. World's Poultry Science Journal, 65: 481-492.

Usman, Kamaruddin, Adhiyudanto, N.B., \& Laining, A. 2011. Penggunaan pakan berbasis bungkil kopra pada pembesaran ikan bandeng di Tambak. Laporan Hasil Penelitian. Balai Penelitian dan Pengembangan Budidaya Air Payau. Maros, $17 \mathrm{hlm}$.

Woodrof, J.G. 1979. Coconut: production, processing and product. $2^{\text {nd }}$ Edition. The AVI Publ. Co. Inc., Wesport, Connecticut, 165 pp. 